\title{
Influence of Organizational Resources on Organizational Effectiveness
}

\author{
Grace Mirigo Mwai, Juliana Mulaa Namada, Paul Katuse \\ Chandaria School of Business, United States International University Africa, Nairobi, Kenya \\ Email: gracemwaidba@gmail.com
}

How to cite this paper: Mwai, G.M., Namada, J.M. and Katuse, P. (2018) Influence of Organizational Resources on Organizational Effectiveness. American Journal of Industrial and Business Management, 8, 1634-1656.

https://doi.org/10.4236/ajibm.2018.86109

Received: May 24, 2018

Accepted: June 24, 2018

Published: June 27, 2018

Copyright $\odot 2018$ by authors and Scientific Research Publishing Inc. This work is licensed under the Creative Commons Attribution International License (CC BY 4.0).

http://creativecommons.org/licenses/by/4.0/

\begin{abstract}
The research purpose was to examine the influence of available resources on organizational effectiveness. The research philosophy was positivism, with explanatory and descriptive research design espoused. The population was registered non-governmental organizations (NGOs), with the sample unit as the project managers. A questionnaire was used for data collection. Data analysis was executed using inferential and descriptive statistics. The descriptive analysis included standard deviation, mean and percentages, whereas inferential analysis included regression analysis and ANOVA. The study concluded that fundraising efforts and how funds are distributed to the various strategic activities and operations influence the level of efficiency in the organization process. Staff empowerment, negatively though, significantly influenced process efficiency. The recommendation is to develop an NGO organizational effectiveness ranking metric to allow the classification of NGOs into categories based on levels of effectiveness in achieving their respective missions and strategies. It was also the aim to carry out an in-depth study of why fundraising efforts in NGOs did not significantly influence stakeholder satisfaction.
\end{abstract}

\section{Keywords}

Organization, Resources, Organizational Effectiveness, Fundraising, Resource-Based View

\section{Introduction}

Organizations have a myriad of challenges that require implementation of corporate strategies for them to remain competitive [1]. Suggested factors that ensure an organization's success in strategy implementation are: providing financial incentives to the staff members and teams when they meet objectives as stated in the strategy; developing a work plan listing strategic intents and re- 
sponsibilities for each department being assigned; and personnel participation in the strategy formulation process to create ownership of the strategy during the implementation stage [2]. In order to enhance organizational effectiveness, senior management teams strive for better leadership, direction, communication, adaptability, interaction and a positive environment to improve organizations effectiveness [3].

Organizational effectiveness is defined as the proficiency with which a firm can meet its objectives by meeting the planned outcome without waste or within minimum use of energy, money, labor and time resources [4]. Organizational effectiveness is also viewed as the extent to which an organization's main tasks are accomplished and finalized with the construct of effectiveness being compactly associated with successful organization's performance [5]. To measure effectiveness, a criterion was proposed that includes the followings: overall success, market share, profitability, growth rate and innovation [6]. Commonly proposed measures of organizational effectiveness for a firm are net profitability compared to budgeted profitability, growth achieved over a planning period, and customer satisfaction [7].

The main difference between organizational efficiency and organizational effectiveness is that organizational efficiency is an indicator of the performance of input and output ratio whereas organizational effectiveness reflects the degree of improvement of internal processes of the organization, such as organizational culture, structure, culture and community [8]. Organizations that are efficiency-oriented focus on sales, quality and creation of benefit, outputs, innovation and cost reduction [9]. Organizational effectiveness aids in the assessment of the progress made towards fulfillment of mission and achievement of goals [3]. Aligning an organization to the strategy assists in solving the problem of communication, especially challenges of formal reporting and bureaucracy that affect organization effectiveness [10]. Efficiency is broader than effectiveness, because efficiency refers to the amount of resources, for example raw materials, labor, and funds, used to achieve a certain outcome in an organization, whereas effectiveness is the ability to achieve set objectives or strategy [1].

NGOs provide certain benefits to society, including awareness of issues of public concern, and the needs of specific groups not taken care of by the government. Often, they are more cost-effective than their private or public organizations or institutions and tend to focus on social impact and community empowerment [11]. Moreover, the extensive networks of NGOs are different from, and more effective than, those of the typical multinational enterprise or national government. This is because they often have to work in challenging settings or with underserved populations, also because they generally enjoy a great degree of legitimacy in the eyes of the public [11].

The global NGO sector has shown trends towards improved mass literacy, a larger middle class in developing nations, and an increase in women in political positions. Suggestions to increase the success for NGOs and overcome chal- 
lenges have included the use of systematic thinking to seek ways to receive feedback timely, unique collaborations with partners to allow leverage of resources, and research and experimentation on innovative approaches [12] [13]. Traditionally, NGOs depended on donors for funding; however, the increased number of NGOs competing for donor funding has constrained the amount and level of funding available for each NGO [14].

Resources are the tangible and intangible assets a firm uses to choose and implement its strategies [15]. Internal resources of the different firms in the same sector are usually heterogeneous [16]. While a well-formulated strategy, a strong and effective pool of skills, and human capital are extremely important resources for strategy success, poor leadership in the utilization of resources is one of the main obstacles in successful strategy implementation, leading to failed organizations [17]. The concept of resources includes all assets, capabilities, organizational processes, firm attributes, information, and knowledge that are controlled by a firm to enable it conceive of and implement strategies that improve its efficiency and effectiveness [18].

Reference [19] supports the importance of human resources in implementing strategies in organizations and clarifies that for a strategy implementation to succeed, top management must be heavily involved in monitoring and reviewing the progress of each strategic program created by the company. Reference [19] further notes that human resources management plays an important role in the effective implementation of strategic plans. According to [20], NGO leaders in Kenya face extraordinary challenges both at a personal and organizational level. Leaders of NGOs work long hours with limited resources in uncertain and volatile political and economic circumstances, while at the same time they are expected to lead efficient organizations [21].

The management teams of NGOs pursue multiple bottom lines as follows: Fundraising, attaining sustainability, achieving donor expectations, meeting national and international government regulations, and managing the environment and societal stakeholders [22]. Despite changes in membership and leadership, an organization's culture is traditionally passed on from generation to generation by creating stability over time [23]. The NGO coalition using the Internet and online lobbying for the Mine Ban Treaty on March 1, 1999 helped create a fresh form of diplomacy, facilitated coordination and reduced networking costs; they were awarded the Nobel Peace Prize [24], after which many NGOs took an interest in online fundraising and have collaborated to raise their causes to great success. Effective nonprofit organizations have fundraising programs that methodically identify multiple sources [25].

Fundraising is defined as the sourcing of assets and resources from different sources for the furtherance of an organization's objective or towards a defined project [26]. Possible multiple sources for NGOs include foundation grants, international donor agencies awards, national government grants, corporate sponsorship and contributions from friends. Only 46 percent of those who were 
donors in 2014 made repeat gifts to the participating nonprofit organizations in 2015, as reported by the 2016 Fundraising Effectiveness Project report [27]. In their study on NGOs, [28] concludes that gender equality of labor markets leads to better utilization of women's work and available resources in all countries. Staff development and employee inspiration can influence the relationship between employee productivity and a leader's traits [29]. Individual gender inclusivity policies are at times seen as a way to balance out the differences in economic and financial incentives between male and female colleagues [30]. Client satisfaction is one of the benefits accrued from efficient operation of the divisions of an entity [31]. Therefore, an organization's effectiveness influences the level of achievement of its strategic intent and goals [9]. This means that organizational structure, allocation of resources, and an innovative organization process lead to more success in strategy implementation and thus the organization's performance [32].

For this study, the dependent variable, organizational effectiveness, was divided into three parameters: Goals attainment, stakeholder satisfaction and process efficiency. Organizational resources the independent variable, was studied in three constructs with respect to the uniqueness of the NGO sector: Fundraising efforts, staff empowerment, and allocation of funds. Organization resources, for purposes of this study, were defined as an organization's assets, skills, capabilities and intangible possessions that are valuable, rare, inimitable, and non-substitutable, which when combined provide an organization with a strategic advantage [33].

The purpose of this study was to examine how organizational resources influence organizational effectiveness of NGOs in Kenya. The null hypothesis was that organizational resources have no influence on organizational effectiveness. The significance of this study is that regulators of the NGO sector can use the findings and recommendations in this study to improve their engagement with NGOs and possibly inform the policies regarding regulation of resources and fundraising, given the uniqueness of the sector. This study also informs management teams of NGOs on perspectives of managing resources and suggestions of practical activities that can be done to influence the effectiveness of organizations.

\section{Literature Review}

This study is grounded on the framework provided by two theories as discussed: Resource based view theory and system theory.

\subsection{Resource Based View Theory}

Resource Based View (RBV) theory was found to be the most suitable theory to explain organizational resources. RBV examines and classifies a firm's strategic advantages informed by the combination of capabilities, skills, assets and intangible possessions [33]. The underlying premise of RBV theory is that a firm 
differs in fundamental ways because each firm possesses, internally, a "unique" bundle of resources-both tangible and intangible assets-which the organizational capabilities then make use of [33]. The resources and capabilities enable the organization to achieve a competitive advantage [34]. In the context of this theory, it is evident that the resources a firm owns influence its strategic implementation process and are important for a firm to develop competencies from its resources, which form part of the firm's competitive advantage [33].

In RBV theory, the competitive advantage, superior performance and effectiveness of an organization explain the distinctiveness of the firm's capabilities [35]. RBV theory provides four characteristics of resources. First, they are valuable, and are therefore used to exploit opportunities and/or neutralize threats in a firm's environment. Second, they are rare among a firm's current and potential competitors. Third, they are inimitable and cannot be replicated. Lastly, they are non-substitutable and distinct, so another product or service cannot have met the same use [34]. RBV theory sets the premise that an organization is a broader set of resources and the growth of an organization involves the exploitation of its existing resources and development of new ones [33].

RBV proposes that unique resources and capabilities are available to enhance a firm's strategy in various forms: Distinctive competencies, core competencies, invisible assets, core capabilities, internal capabilities, embedded knowledge, corporate culture, and unique combinations given a firm's process and experience [34]. Organizational effectiveness differs across firms and as argued by [15], RBV explains why firms in the same sector are different, arising from the heterogeneous strategic resources that the firm's own and control. This postulates that heterogeneity in resources which are immobile is a key characteristic in sustaining competitive advantage [15].

RBV theory also argues that strategy implementation for firms must continually strive to acquire, develop and upgrade resources and capabilities if they are to maintain competitiveness and growth in a changing organizational environment [36]. RBV theory provides a definition of resources as rare, valuable, inimitable and non-substitutable advantages that lead to a firm's sustainable competitive advantages [15]. The RBV model suggests that the resources possessed by a firm are the primary determinants of its performance and success, and these contribute to a sustainable competitive advantage of the firm [37].

The concept of resources includes all assets, capabilities, organizational processes, firm attributes, information, and knowledge that are controlled by a firm to enable it conceive of and implement strategies that improve its efficiency and effectiveness [37]. In the RBV model, the main concern of a firm is identification of characteristics of resources that are not subject to imitation by competitors. The sustainability of a firm's strategic position hinges on how easily its resources can be substituted or imitated, and imitability is linked to the characteristics of the resource accumulation process-time compression diseconomies, resource efficiencies, inter-connectedness, resource erosion, and casual ambiguity [16]. 
The RBV theory has been criticized for assuming that the relative superiority of resources determines the results of competition, neglecting those firms that go to great lengths to protect their source of sustainable competitive advantage by inhibiting the value creation of their competitors, for example through engaging in bribery [38]. This may result in unethical practices, for example the use of employees to get confidential intellectual information or to gain access to trade secrets of the competition. A firm can also hinder competitors from acquiring and retaining talent, thus preventing their rival's profit realization from resources and resulting in their own competitive advantage [39].

Another criticism of the RBV theory is that organizations have difficulty in resource acquisition given certain types of restraints, including in the regulation or transfer of human resources [40]. RBV theory ignores that a firm can exert negative as well as positive influence on its surrounding business environment. If a firm already has access to a superior resource, it may exploit that position to jostle out any other competitor, leading to monopolistic industries [40]. Innovation and a firm's results also account for a significant portion of the value added in modern firms, thus it which makes it limiting to say that RBV is the only cause of competitive advantage [41].

Critics of the RBV theory argue that it sometimes causes a firm to deliberately create market imperfections by lobbying for hindrances to market entry. The barriers to entry lower the competitor's value through limitation on intellectual capital and patent access, which causes restriction to a firm's services [42]. Innovation, when used to gain a competitive edge, not only leads to generation of a firm's own value, it lowers the value of competitors' resources. This leads to competitive superiority through leadership in innovative activities [41].

The other criticism of the RBV theory is that it assumes that firms are profit-maximizing entities directed by boundary-conscious managers operating in distinctive markets that are to some extent predictable and moving towards market equilibrium [43] [44]. RBV also assumes that information about the future value of a resource is asymmetrically distributed, which is not always the case. Other critics of the RBV theory argue that it has no managerial implications and implies infinite regress. They also state that its applicability is too limited and that sustained competitive advantage is not achievable. Further, they posit that RBV is not a theory of the firm and that valuable, rare, inimitable, and non-substitutable characteristics are neither necessary nor sufficient for sustained competitive advantage. The value of a resource is therefore too indeterminate to provide for useful theory. Lastly, the definition of a resource is unworkable [45].

The RBV theory is important to this study since it provides characteristics of an organization's strategy and its specific resources, which are the main sources of competitive advantage that drive a firm's strategy and organizational effectiveness. This theory argues that a firm's effectiveness will often hinge on unique resources that cannot be easily substituted or imitated [16]. Moreover, non-imitability links to the characteristics of the organization's process of re- 
source accumulation. Whereas the process is informed by the time it takes a resource to reduce diseconomies of scale and the inter-connectedness of resources that creates unique capability, there is a slow rate of resource erosion and casual ambiguity [16].

The RBV theory grounds this research's independent variable, strategic management, and its sub variables-combination of organization resources, leadership style, and structure culture-for two or more organizations can have similar strategies but differ in competitive edge given the strategy execution. Such a difference is dependent on the characteristics and the mix of the valuable resources, that is, leadership, organization structure, culture and resources, to produce an organization capability that leads to unique competitive advantages.

\subsection{Systems Theory}

The systems theory is said to have originated from economics, engineering, and biology. It focuses on how interrelationships can be generalized across various organizational schemes to understand the organization's relationship with its environment [46] [47]. The concept of General Systems Theory (GST) was first advanced by Ludwig von Bertanlanffy in 1940 and is primarily concerned with how systems operate. It integrates with other systems by naming and identifying patterns and processes common to all of them [46] [48].

The dichotomy between closed and open systems is difficult to apply to social organizations since most of them are partially "open" and partially "closed" [49]. The systems theory emphasizes on boundary, environment, feedback and adaptive response. These emphases presume the management is readily identified as the control center, creating a weakness since it overestimates a management team member's power to control events and actions [50]. With system theory informing that managers should focus on the role played by each part of an organization, rather than dealing separately with the parts, both interpersonal and group behavioral aspects are emphasized, leading to a system of cooperation [51].

The systems theory views an organization as a social system consisting of individuals who cooperate within a formal framework, drawing resources, people and finances from their environment and putting them back into that environment through the products they produce or the services they offer [52]. Thus, a system does include an organization's resources and how these interact with other internal and external factors affecting an organization. The systems theory underpins the organization's effectiveness given the different open or closed systems responding to external influences, for example resources (financial, skills and personnel) available from funders and sponsors for NGOs as they attempt to achieve their strategic objectives and to be effective.

\subsection{Organization Resources and Organizational Effectiveness}

The research on the structure and resources of NGOs in Estonia reveals the ex- 
istence of two main types of resources for successful organizational effectiveness. One is formal and is common for international NGOs that have structured communication, fundraising subcommittees, formal membership subscriptions and compensated staff. The second is informal and often used by community groups, cultural and recreational associations; resources are managed informally, it is non-bureaucratic and direct communication often cuts across the group [53]. The results indicate the limited material, legislative, and moral resources to fulfill their civic and political expectations in Estonia.

The resources structure adopted was informed by different factors: $\mathrm{Pa}$ tron-client relationships are often based on personal loyalty and relationships, the effect of NGO umbrella associations exerting their influence and petitioning the national legislature, and how resources influence the internal democracy in NGOs, leading to an organization meeting its mission and goals effectively [53]. The NGOs active in the bigger cities in Estonia were ahead of those located in small towns and rural areas in their capacity to attract resources and their capability in using the available resources. A study on financial resources of NGOs in Romania reveals that "application" is the main tool used to request for funds by NGOs [54]. The main funds sources for NGOs in Romania are broadly divided into two categories. The first category is local funds received from within the country. The second category is the donations received from abroad.

Direct funding is obtained through grants allocated from the state budget and given through the ministries. The national government has institutions at the national level that focus on international funding programs for the non-profit sector. There is also direct material support provided by local authorities, revenues from the economic or profit-making activities of the NGOs, and membership fees [54]. The important elements of an organization fundraising plan are: A written plan indicating purposes and objectives; justification for the request of a donation; variety of targeted funding sources; time allocated for fundraising; money allocated for fundraising; and members and board hired or tasked with the fundraising activities [54]. A research on corporations and NGOs shows distinct co-optation between the for-profit and nonprofit sectors because of the increased engagement of NGOs in business-type activities, with sponsorship causing a resource dependency for NGOs [55].

Corporate sponsorship succeeds when the NGO and for-profit company are not in a competing sector or service. This is exemplified well in the example where the NGO, Save the Children, sought corporate sponsorship from companies such as Coca-Cola and Pepsi, where their focus was on child obesity in the United States. Corporate product endorsement by NGOs and appointing some of the for-profit leaders into their board of directors ensures access to resources that NGOs would otherwise not have access to [55].

Reference [56] examined the relationship between organizational resources, capabilities, systems and competitive advantage. Competitive advantage was from the perspective of "value and quality", the main elements of which are de- 
scribed as "cost-based", "product-based" and "service-based". Their research was conducted among manufacturers listed in the 2008 Federation of Malaysian Manufacturers Directory. Their findings indicate significant, positive effects of organizational resources, capabilities and systems collectively on competitive advantage, providing support and corroboration to the resource-based view (RBV). The limitation to their study is that generalizability of the findings is not recommended given the sample only captured perception of a single respondent, that is, the top management per manufacturer at a single point in time [56]. A study on the social marketing strategies provided the characteristics of marketing strategies of NGOs and how they have affected the organization's effectiveness in vision and mission achievement [57]. The study concluded that NGOs are relatively weaker in social marketing than their counterparts in for-profits that use aggressive commercial marketing strategies. Marketing benefits are not easily attributable to the success of NGOs in fundraising; social and cultural stigma barriers do not favor NGOs to market, with too many stakeholders influencing the social marketing plans.

In an analysis of factors influencing the implementation of strategic plans in public secondary schools in Mukurweini and Othaya sub-counties of Nyeri County in Kenya, the objectives focused on the influence of managerial skills, institutional policies, allocation of resources, rewards, and incentives on implementation of strategic plans [58]. The results indicated the need for resource allocation policies and prioritization of budget development. A proposed priority was establishment of institution policies and management team training on core skills to enable implementation of the strategy. A unique finding is that rewards and financial incentives did not influence implementation of strategic plans in public secondary schools.

Reference [59] studied factors influencing strategy implementation of water supply firms in Mombasa, Kenya. The study variables were leadership, organizational culture, organizational resources, and stakeholders. The study used stratified random sampling technique to choose employees from three departments that were issued with the questionnaire. The study concluded that lack of commitment of top management teams to strategy implementation, poor leadership style and guidance from managers, inadequate human resource skills, limited funds, and interference from stakeholders lead to poor strategy implementation.

A study on resource-dependency perspectives in the implementation of strategic plans in NGOs in Kenya concludes that many NGOs have embraced strategic planning, but the implementation to meet goals and results has remained a challenge [60]. The study concluded that the key challenge, resources, has caused NGOs to give importance to top leadership to provide firms with the comparative advantage to raise funds for projects and for the organization's sustainability [60]. The Internet can be used to create awareness and raise resources as it was done for an international operation to veto landmines; in the latter case, the research analyzed the efforts, leading to the International Mine Ban Treaty signed in 1999 [24]. 


\section{Methodology}

\subsection{Research Design}

Descriptive and explanatory research design was employed in this study. The research methodology sought to examine the extent to which organization resources influence organizational effectiveness. The descriptive design was suitable for this study since it involved intricate analysis of the influence of organization resources on organization effectiveness. This design was adopted due to its usefulness in studies to test the relationship between variables in a population. On the other hand, the explanatory research design was suited for the study as it sought to explain how a change in the independent variables, organization resources affects the dependent variable organizational effectiveness. Descriptive design parameters were organization size and period of NGO in operation. Explanatory design is used to explain through using regression analysis to examine the relationship between organization effectiveness constructs and organizational resources.

\subsection{Population and Sample}

The study population comprised Kenyan non-governmental organizations (NGOs). The study focused on project managers on NGOs registered in Kenya. The population was 5547 project managers of NGOs registered with the NGO Board of Kenya by the year 2016. Project managers studied in the NGOs were the persons leading the projects, often designated as chief of party or team leaders or executive directors. Simple random sampling technique was implemented to draw out the sample size of 374 project managers from the total population. Simple random sampling reduced bias and gave each NGO in Nairobi a chance to participate. The choice of NGO's project managers was because they are the ones responsible for strategy implementation and are best placed to provide the information; this is similar to [20] research.

\subsection{Validity, Reliability and Ethics}

A questionnaire with both closed and open-ended questions was used. The researcher was given approval to proceed by the research office at USIU-A and a research permit was granted by the National Commission for Science, Technology and Innovation, in Kenya. They regulate and assure quality in the science, technology and innovation sector research. The questionnaires were reviewed by research experts and a sample of NGO industry leaders. A pilot study was done and had a Cronbach's alpha for organization resources at 0.726 and organizational effectiveness at 0.838 , values that were satisfactory. The identities and contacts of all the respondents were kept confidential.

\subsection{Model}

Prerequisite analysis for regression tests was done. The data met the prerequisite tests. To predict the effect of organization resources on organizational effective- 
ness a linear equation was used. This is referenced to the hypothesis under study. The linear equation model was stated as:

$$
Y=\alpha_{0}+\alpha_{1} X_{1}+\alpha_{1} X_{2}+\alpha_{1} X_{3}+e
$$

where, $Y=$ Organizational effectiveness (made up of three parameters, goals attainment, stakeholders' satisfaction and process efficiency); $\alpha=$ constant value; $X_{1}=$ fundraising efforts; $X_{2}=$ staff empowerment; $X_{3}=$ Allocation of funds; $e$ $=$ error term.

\section{Analysis and Findings}

The null hypothesis, organizational resources do not significantly influence organizational effectiveness, was tested in this section. The response rate for the study was 73.5 percent.

\subsection{Demographics}

\subsubsection{Organization Size}

The respondents indicate the size of the organization measured by the number of employees. Table 1 shows the results for the size of the organizations.

The results indicate the organization's size by measuring the number of employees. Most of the NGOs have less than 20 employees. From the study, 50.9 percent of the organizations had no more than 20employees, while 35.3 percent of them had between 21 and 50 employees. A further 5.8 percent of the organizations had from 51 to 100 employees, while only 8 percent had more than 100 employees. This supports the general data from the NGO Board records that a majority of NGOs in Kenya are not large in employee size and often rely on donations; thus, they are not able to retain a large number of staff members.

\subsubsection{Period of NGO Operation in Kenya}

The respondents indicated how long their organization had been in operation in Kenya. The results are shown in Table 2.

The respondents indicated that of among the NGOs who participated in the survey, 10.2 percent had been in operation for less than 5 years, 32 percent for 5 to 10 years, 20 percent for 11 to 15 years, and 17.5 percent for 16 to 20 years. The study also reveals that 7.6 percent of NGOs have been in operation for 21 to 25 years, 4.7 percent for 26 to 30 years, and 2.5 percent for 31 to 35 years. The remaining 5 percent of NGOs operating in Kenya have been in existence for over

Table 1. Organization size.

\begin{tabular}{ccc}
\hline Number of Employees & Count & Column N \% \\
\hline 20 and below & 140 & 50.9 \\
$21-50$ & 97 & 35.3 \\
$51-100$ & 16 & 5.8 \\
$>100$ & 22 & 8.0 \\
Total & 275 & 100
\end{tabular}


Table 2. Period of work in Kenya.

\begin{tabular}{ccc}
\hline Period of work in Kenya (years) & Frequency & Percentage \\
\hline$<5$ & 28 & 10.2 \\
$11-15$ & 88 & 32.0 \\
$16-20$ & 55 & 20.0 \\
$21-25$ & 48 & 17.5 \\
$26-30$ & 21 & 7.6 \\
$31-35$ & 13 & 4.7 \\
$36-40$ & 7 & 2.5 \\
$41-45$ & 4 & 1.5 \\
$46-50$ & 4 & 1.5 \\
$56-60$ & 4 & 1.5 \\
$>61$ & 2 & 0.7 \\
Total & 1 & 0.4 \\
\hline
\end{tabular}

36 years. This study results reveals that most of the organizations have been registered as NGOs in Kenya between 5 to 10 years ago, which can be attributed to changing laws and policies in recent years that have provided clarity on the process and governance of NGOs, leading to their increased registration.

\subsection{Descriptive Statistics of Organizational Resources}

The descriptive results for the variable "organization resources" were provided in terms of the mean, standard deviation and variance. The standard deviation shows how close to the mean the respondent's data is, and a large standard deviation means that the values in the data set are farther away from the mean. Variances with large values represent greater dispersion. The descriptive of the variables measuring resources are laid out in Table 3.

The mean for organization resources ranged from 2.39 to 4.70 . The findings of the study mean that organizational resources affect the organizational effectiveness of NGOs in Kenya. The study shows that respondents strongly disagreed on the statement that staff empowerment enhances organizational goal attainment. The respondents also strongly agreed with the statement that fundraising efforts support process efficiency. Organizational resources and organizational effectiveness had standard deviations ranging from 0.564 to 1.595 . This means that there is a great variation in the respondents' opinions on how organizational resources affect organizational effectiveness.

\subsection{Influence of Resources on Organizational Effectiveness of NGOs}

\subsubsection{Model Summary}

The influence of organizational resources on organizational effectiveness of 
Table 3. Descriptive analysis of organizational resources.

\begin{tabular}{|c|c|c|c|c|}
\hline Statement & $\mathrm{N}$ & Mean & Std. Dev & Variance \\
\hline $\begin{array}{l}\text { Fundraising efforts influence realization of organizational } \\
\text { goals }\end{array}$ & 275 & 4.29 & 0.914 & 0.836 \\
\hline $\begin{array}{l}\text { Efforts in fundraising ensures satisfaction of organization } \\
\text { stakeholders }\end{array}$ & 275 & 4.58 & 0.564 & 0.318 \\
\hline Fundraising efforts support process efficiency & 275 & 4.70 & 0.525 & 0.276 \\
\hline $\begin{array}{l}\text { Staff empowerment enhances organizational goal } \\
\text { attainment }\end{array}$ & 275 & 2.39 & 1.292 & 1.670 \\
\hline Staff empowerment influences stakeholder satisfaction & 275 & 3.88 & 1.093 & 1.194 \\
\hline $\begin{array}{l}\text { Staff empowerment supports organizational process } \\
\text { efficiency }\end{array}$ & 275 & 3.54 & 1.150 & 1.322 \\
\hline Allocation of organizational funds helps in goal attainment & 275 & 2.74 & 1.263 & 1.595 \\
\hline $\begin{array}{l}\text { Effective allocation of funds enhances satisfaction of the } \\
\text { organization's stakeholders }\end{array}$ & 275 & 3.46 & 1.169 & 1.366 \\
\hline $\begin{array}{l}\text { Allocation of funds supports process efficiency in the } \\
\text { organization }\end{array}$ & 275 & 4.35 & 0.859 & 0.738 \\
\hline
\end{tabular}

NGOs was investigated by fitting a regression model with the mean score of organizational resources as the independent variable and the mean score of organizational effectiveness as the dependent variable. The model fit of the regression analysis was presented in Table 4.

Table 4 indicates an adjusted R-squared value of 0.018 . This means that resources can explain 1.8 percent of the variance in organizational effectiveness. The 98.2 percent is accredited to the error term and variables not examined in this research.

\subsubsection{ANOVA Test Organization Resources on Organizational Effectiveness}

The results of the ANOVA test were as indicated in Table 5.

ANOVA tests the null hypothesis that the regression model with resources as the independent variable explains zero variance in organizational effectiveness as the dependent variable. The F-Statistic from ANOVA test explains the overall significance of the regression model at 95 percent confidence interval. The criteria for rejecting the null hypothesis is to reject the null hypothesis if the p-value of the F-Statistic is less than the p-value at 95 percent confidence level $=0.05$. The results show that the F-Statistic of 6.122 is statistically significant with a p-value of $0.014<0.05$. This means that the model with resources as the independent variable explains a significant variance in organizational effectiveness.

\subsubsection{Coefficient Analysis}

The details of each resource variable's construct coefficient analysis are shown in Table 6.

Two constructs are significant and have positive coefficients; fundraising efforts support process efficiency at 0.236 and allocation of funds supports process 
Table 4. Model summary of variable "organizational resources".

\begin{tabular}{cccccc}
\hline Model & $\mathrm{R}$ & R Square & Adjusted R Square & Std. Error of the Estimate & Durbin-Watson \\
\hline 1 & $0.148^{\mathrm{a}}$ & 0.022 & 0.018 & 0.54262 & 1.804 \\
\hline
\end{tabular}

a. Dependent Variable: Organizational Effectiveness; b. Predictors: (Constant), Organizational Resources.

Table 5. ANOVA test for organizational resources on organizational effectiveness.

\begin{tabular}{cccccc}
\hline \multicolumn{5}{c}{ ANOVA $^{\mathrm{a}}$} \\
\hline Model & Sum of Squares & Df & Mean Square & F & Sig. \\
\hline Regression & 1.802 & 1 & 1.802 & 6.122 & $0.014^{\mathrm{b}}$ \\
Residual & 80.381 & 273 & 0.294 & & \\
Total & 82.183 & 274 & & & \\
\hline
\end{tabular}

a. Dependent Variable: Organizational Effectiveness; b. Predictors: (Constant), Organizational Resources.

Table 6. Detailed coefficients of variable "organizational resources".

\begin{tabular}{|c|c|c|c|c|c|c|c|}
\hline \multirow[t]{2}{*}{ Model } & \multicolumn{2}{|c|}{$\begin{array}{l}\text { Unstandardized } \\
\text { Coefficients }\end{array}$} & \multirow{2}{*}{$\begin{array}{c}\text { Standardized } \\
\text { Coefficients }\end{array}$} & \multirow[t]{2}{*}{$\mathrm{t}$} & \multirow[t]{2}{*}{ Sig. } & \multicolumn{2}{|c|}{$\begin{array}{l}\text { Collinearity } \\
\text { Statistics }\end{array}$} \\
\hline & B & Std. Error & & & & Tolerance & VIF \\
\hline (Constant) & 2.095 & 0.420 & & 4.993 & 0.000 & & \\
\hline $\begin{array}{c}\text { Fundraising efforts } \\
\text { influence realization of } \\
\text { organizational goals }\end{array}$ & 0.066 & 0.035 & 0.110 & 1.874 & 0.062 & 0.944 & 1.059 \\
\hline $\begin{array}{c}\text { Efforts in fundraising } \\
\text { ensures satisfaction of } \\
\text { organization stakeholders }\end{array}$ & 0.028 & 0.063 & 0.029 & 0.452 & 0.652 & 0.778 & 1.286 \\
\hline $\begin{array}{c}\text { Fundraising efforts } \\
\text { support process efficiency }\end{array}$ & 0.246 & 0.066 & 0.236 & 3.756 & 0.000 & 0.819 & 1.222 \\
\hline $\begin{array}{c}\text { Staff empowerment } \\
\text { enhances organizational } \\
\text { goal attainment }\end{array}$ & 0.007 & 0.025 & 0.017 & 0.278 & 0.781 & 0.913 & 1.096 \\
\hline $\begin{array}{c}\text { Staff empowerment } \\
\text { influences stakeholder } \\
\text { satisfaction }\end{array}$ & 0.002 & 0.030 & 0.004 & 0.067 & 0.947 & 0.926 & 1.079 \\
\hline $\begin{array}{c}\text { Staff empowerment } \\
\text { supports organizational } \\
\text { process efficiency }\end{array}$ & -0.071 & 0.031 & -0.149 & -2.308 & 0.022 & 0.770 & 1.298 \\
\hline $\begin{array}{c}\text { Allocation of } \\
\text { organizational fund helps } \\
\text { in goal attainment }\end{array}$ & 0.050 & 0.027 & 0.115 & 1.875 & 0.062 & 0.861 & 1.161 \\
\hline $\begin{array}{l}\text { Effective allocation of } \\
\text { funds enhances } \\
\text { satisfaction of the } \\
\text { organization's } \\
\text { stakeholders }\end{array}$ & 0.010 & 0.030 & 0.022 & 0.337 & 0.736 & 0.769 & 1.300 \\
\hline $\begin{array}{l}\text { Allocation of funds } \\
\text { supports process } \\
\text { efficiency in the } \\
\text { organization }\end{array}$ & 0.134 & 0.037 & 0.210 & 3.582 & 0.000 & 0.936 & 1.068 \\
\hline
\end{tabular}


efficiency in the organization at 0.210 . One construct is significant and has negative coefficients; staff empowerment supports organizational process efficiency at -0.149 .

Six constructs are not significant and have positive coefficients: Fundraising efforts influence realization of organizational goals; efforts in fundraising ensure satisfaction of organization stakeholders; staff empowerment enhances organizational goal attainment; staff empowerment influences stakeholder satisfaction; allocation of organizational funds helps in goal attainment; and effective allocation of funds enhances satisfaction of the organization's stakeholders. Table 7 shows the combined coefficient for organization resources.

The standardized coefficient is 0.148 and $\mathrm{p}$ value is 0.014 . The study used linear regression model to test the relationship between organizational resources and organizational effectiveness in NGOs in Kenya. The model is:

$$
Y=\alpha_{0}+\alpha_{1} X_{1}+\alpha_{1} X_{2}+\alpha_{1} X_{3}+e
$$

The study thus represents organizational effectiveness as:

Organizational effectiveness $=3.541+0.148$ organization resources $+e$.

Therefore, a unit change in organizational resources causes a change of 0.148 in organizational effectiveness. The third research question's hypothesis was; Resources do not significantly influence the organizational effectiveness of NGOs in Kenya. The criteria for rejecting the null hypothesis is to reject the null hypothesis if the $\mathrm{p}$-value of the F-Statistic is less than the p-value at 95 percent confidence level $=0.05$. The hypothesis was tested using a linear regression model as per the regression coefficient results in Table 4.19 which show a $\mathrm{p}$ value of 0.014 , therefore the null hypothesis is rejected and the alternate, organization resources significantly influence the organizational effectiveness of NGOs in Kenya, is accepted.

\section{Discussion}

The research results indicate a significant relationship between organizational resources and organizational effectiveness at a p-value of 0.014 , which is significant at 0.05 . The organizational resources cause 1.8 percent variation in organizational effectiveness, $(\mathrm{R} 2=0.018, \mathrm{~F}(1273)=6.122, \mathrm{p}<0.05$. The multiple regression analysis shows that only three parameters are significant. These are that fundraising efforts support organizational process efficiency, $\beta=0.236, t(275)=$ $3.756, \mathrm{p}<0.05$; staff empowerment supports organizational process efficiency, $\beta$

Table 7. Coefficients of organizational resources and organizational effectiveness.

\begin{tabular}{|c|c|c|c|c|c|c|c|c|}
\hline & \multirow[t]{2}{*}{ Model } & & \multirow{2}{*}{$\begin{array}{c}\text { Unstandardized } \\
\text { Coefficients }\end{array}$} & \multirow{2}{*}{$\begin{array}{c}\text { Standardized } \\
\text { Coefficients }\end{array}$} & \multirow{2}{*}{$\begin{array}{c}\mathrm{t} \\
\text { Beta }\end{array}$} & \multirow[t]{2}{*}{ Sig. } & \multicolumn{2}{|c|}{$\begin{array}{c}\text { Collinearity } \\
\text { Statistics }\end{array}$} \\
\hline & & & & & & & Tolerance & VIF \\
\hline \multirow{2}{*}{1} & (Constant) & 3.541 & 0.264 & & 13.400 & 0.000 & & \\
\hline & Resources & 0.176 & 0.071 & 0.148 & 2.474 & 0.014 & 1 & 1 \\
\hline
\end{tabular}

a. Dependent Variable: Organizational Effectiveness. 
$=-0.149, t(275)=-2.308, \mathrm{p}<0.05$; and allocation of funds supports process efficiency in the organization, $\beta=0.210, t(275)=3.582, \mathrm{p}<0.05$.

This study shows that organizational resources are significant in enhancing organizational effectiveness. The first parameter examined the influence of fundraising efforts on organizational goals and the result was positive but insignificant. The findings of the study support the findings of [24], who stated that fundraising is pursued by the management teams of NGOs and helps in achieving their goals. The Internet is used to campaign and create coalitions that regularly raise resources, leading to the realization of organizational goals.

The second parameter examined the influence of fundraising efforts in satisfaction of organization stakeholders and found a positive but insignificant impact. This was different from [25], who posits that because fundraising is a critical process of NGOs, many of such organizations have taken fundraising online and are collaborating to raise enough funds to pursue their purpose. This differs from [53], whose study revealed that organizational resources influence the internal democracy in NGOs, leading to an organization meeting its mission and goals effectively.

The third parameter examined the influence of fundraising efforts on organization process efficiency, and the results were positively significant. This research corresponds to the results of [26], who asserts that fundraising is a source of assets and resources from different sources for achieving the objectives of an organization. Reference [54] found that the reasons why resources from fundraising enhance organizational effectiveness had to do with a requirement that an NGO sourcing for funds had to have a written plan indicating the purposes and objectives of the fundraising.

The fourth parameter examined the influence of staff empowerment on the realization of organizational goals, and the results were positively insignificant. This study differed from [55], who argued that corporate product endorsement by NGOs and the appointment of donor representatives to become part of the governance board ensures access to resources of networks that an NGO would otherwise not have had access to, which is a form of co-optation. This study differs from [28], who found that gender equality of labor markets leads to better utilization of the women's work, by use of skilled resources to achieve organizational goals.

The fifth parameter examined the influence of staff empowerment on stakeholder satisfaction, and the result was positively insignificant. Reference [56] findings diverged in asserting that competitive advantage in the NGO sector is from the perspective of value and quality derived from all resources held and is then passed on to different stakeholders. This study agrees with [57], that NGOs are relatively weaker in social marketing than their counterparts in for-profit organizations that use aggressive commercial marketing strategies. Furthermore, they state that marketing benefits are not easily attributed to the success of NGOs in fundraising, hence employee empowerment is the best tool to use to 
achieve that mission. This study deviates from [58], who found that staff empowerment enhances effective resource allocation to achieve organizational goals and satisfy an organization's stakeholders. Their study found that institutional policies and management team training on core skills to enable implementation of the organizational strategy is critical in achieving organizational effectiveness.

The sixth parameter examined the influence of staff empowerment in making organization processes efficient, and the result was negatively significant. Reference [56] comes to a different understanding, with their findings showing that organizational resources enhance competitive advantage; this provides support to the resource-based view in ensuring organizational processes are effective. The findings of this study differed from those in [29], who confirmed that employee empowerment was the most effective way to manage and lead employees to perform better given that NGOs focus on people's welfare services. In addition, the study found that the core statement of employee empowerment implies that for organizations to improve staff empowerment, they must effectively manage their strategic process and relationships as well as manage their training managers. These research findings are supported by those of [30], who revealed that empowerment in some instances misses its meaning and is often narrowly examined as gender equality and how women are treated, not gender equity. To further examine this study's finding, that staff empowerment negatively but significantly influences process efficiency, NGOs can adopt individual gender empowerment policies as recommended by [30], as a key means for women to reduce the gap between them and their male counterparts economically, educationally, politically and culturally.

The seventh parameter examined the influence of allocation of organizational funds on goal attainment, and the results were positively insignificant. This finding contradicts the findings of [52] that resource allocation for various units and activities within the business ecosystem is critical for achieving effective organization. Reference [52] argued that effective resource allocation facilitates working relationships between different entities in an organization and improves the working efficiency within the organization units to achieve organizational goals.

The eighth parameter examined the influence of allocation of organization funds on organizations stakeholder satisfaction, and the results were positively insignificant. Reference [31] backs this study, when they state that resource allocation benefits organizational customers by enhancing client satisfaction, which is one of the measures of organizational effectiveness. Reference [9], on the other hand, found that business efficiency informs the performance of input and output ratio because of organizational resources, whereas organizational efficiency is concerned with the enhancement of internal processes of the organization such as structure and culture. The study confirms that organizational efficiency is all about resource allocation across alternative uses to achieve an organizational goal. 
The ninth parameter examined the influence of allocation of organization funds in the efficiency of organizational processes, whose result was positively significant. This finding is mirrored in [59], a study that revealed lack of commitment by the top management team to strategy implementation, poor leadership style and guidance from managers, inadequate human resource skills, limited funds, and interference from stakeholders leading to poor organizational effectiveness. This study agrees with findings of [32], a study that reflected the importance of resources and processes within an organization and proposed that creativity, innovation, and perception of an organization were important processes in successfully implementing strategies.

\section{Conclusion}

From the study, organizational resources were found to positively and significantly influence the achievement of organizational effectiveness. This research established that fundraising efforts positively influence the efficiency of organizational processes. A unique finding was that staff empowerment leads to a negative influence on efficiency; this may be rectified using affirmative policies and great effort, but will not always lead to the best possible efficiency of organizational resources. The distribution of resources leads to positive influence on an organization's ability to meet its organizational strategy and objectives. The study concludes that two parameters of organizational effectiveness-goals attainment and stakeholders-are not significantly influenced by staff empowerment, fund raising efforts and how funds are allocated. The critical and highly significant organization effectiveness construct affected by resources is process efficiency. The results led to a rejection of the null hypothesis that leadership style does not significantly influence the organizational effectiveness of NGOs in Kenya.

\section{Recommendation}

Organizational resources have significant influence on the effectiveness of non-governmental organizations. The study recommends that keen attention be given to how staff empowerment is done and implemented, because it can cause a negative influence on an organization's processes. More in-depth analysis is needed on why staff empowerment neither significantly influenced stakeholder satisfaction nor supported goal attainment.

The study also recommends effective allocation of funds, as this enhances the success of an organization's performance and productivity. Fundraising frameworks and charters are recommended for each NGO, as such efforts will increase organizational effectiveness. Effective allocation of organizational funds also helps in goal attainment. The study recommends the use of fundraising efforts because this influences the realization of organizational goals and enhances the efficiency of organizational processes.

The study was conducted in Kenya. There is a need for similar studies to be 
carried out in other developing countries and to examine the similarities and differences between them. Similarly, there is a need to carry out a similar study while using the funding source as a mediating variable to see if the results will differ. More in-depth analysis or case study analysis of these findings is needed, too, to examine the unique finding that staff empowerment leads to a negative influence on process efficiency. Finally, it is recommended that an NGO organizational effectiveness ranking metric be developed to allow the classification of NGOs; this tool will show how effective these organizations are in achieving their mission and strategy.

\section{References}

[1] Daft, R.L. (2010) Organization Theory and Design. 10th Edition, South-Western Cengage Learning, Mason, USA.

[2] Zepsa, A. and Ribickisb, L. (2015) Strategy Development and Implementation-Process and Factors Influencing the Result: Case Study of Latvian Organizations. Procedia-Social and Behavioral Sciences, 213, 931-937. https://doi.org/10.1016/j.sbspro.2015.11.507

[3] Heilman, S. and Kennedy-Phillips, L. (2011) Making Assessment Easier with the Organizational Effectiveness Model Describe a Comprehensive, Step-by-Step, Mixed-Methods Assessment Model. American College Personnel Association and Wiley Periodicals, 15, 29-32. https://doi.org/10.1002/abc.20046

[4] Lunenburg, F.C. (2012) Organizational Structure: Mintzberg's Framework. International Journal of Scholarly, Academic, Intellectual Diversity, 14, 1-7.

[5] Kafashpoor, A., Shakoori, N. and Sadeghian, S. (2013) Linking Organizational Culture, Structure, Leadership Style, Strategy, and Organizational Effectiveness: Mediating Role of Knowledge Management. Advanced Research in Economic and Management Sciences (AREMS), 10, 158-172.

[6] Lee, H. and Choi, B. (2003) Knowledge Management Enablers, Processes, and Organizational Performance: Integrative View and Empirical Examination. Journal of Management Information Systems, 20, 179-288. https://doi.org/10.1080/07421222.2003.11045756

[7] Yukl, G. (2008) How Leaders Influence Organizational Effectiveness. The Leadership Quarterly, 19, 708-722. https://doi.org/10.1016/j.leaqua.2008.09.008

[8] Pinprayong, B. and Siengtai, S. (2012) Restructuring for Organizational Efficiency in the Banking Sector in Thailand: A Case Study of Siam Commercial Bank. Far East Journal of Psychology and Business, 8, 29-42.

[9] Zheng, W., Yang, B. and McLean, G. (2010) Linking Organizational Culture, Structure, Strategy, and Organizational Effectiveness: Mediating Role of Knowledge Management. Journal of Business Research, 63, 763-771. https://doi.org/10.1016/j.jbusres.2009.06.005

[10] Basuony, M.A.K. (2014) The Balanced Scorecard in Large Firms and SMEs: A Critique of the Nature, Value and Application. Accounting and Finance Research, 3, 14-22. https://doi.org/10.5430/afr.v3n2p14

[11] Nancy, G. and Yontcheva, B. (2006) Does NGO Aid Go to the Poor? Empirical Evidence from Europe. IMF Working Paper, IMF Institute. https://www.imf.org/external/pubs/ft/wp/2006/wp0639.pdf

[12] Thorpe, J. (2014) Business and International Development: Is Systemic Change Part 
of the Business Approach? Institute of Development Studies, Brighton. http://www.ids.ac.uk/publication/business-and-international-development-is-syste mic-change-part-of-the-business-approach

[13] Green, D. (2015) Fit for the Future: Development Trends and the Role of INGOs. Oxfam, Oxford.

http://www.globaltfokus.dk/images/Kapacitetsudvikling/Arrangementer_kap_foru m/dp-fit-for-future-INGOs-110615-Oxfam-en.pdf

[14] Werker, E. and Ahmed, F.Z. (2008) What Do Non-Governmental Organizations Do? Journal of Economic Perspectives, 22, 73-92. https://doi.org/10.1257/jep.22.2.73

[15] Rose, R.C., Abdullah, H. and Ismad, A.I. (2010) A Review on the Relationship between Organizational Resources, Competitive Advantage and Performance, The Journal of International Social Research, 3, 488-498.

[16] Jiang, W. (2014) Business Partnerships and Organizational Performance: The Role of Resources and Capabilities. In: Contributions to Management Science, Springer-Verlag, Berlin, Heidelberg. https://doi.org/10.1007/978-3-642-53989-3

[17] Cater, T. and Pucko, D. (2010) Factors of Effective Strategy Implementation: Empirical Evidence from Slovenian Business Practice. Journal for East European Management Studies, 15, 207-236. http://hdl.handle.net/10419/84060 https://doi.org/10.5771/0949-6181-2010-3-207

[18] Hofer, C.W. and Schendel, D.E. (2006) Strategy Formulation: Analytical Concepts. 2nd Edition, West Publishing, St. Paul, MN.

[19] Rajasekar, J. (2014) Factors Affecting Effective Strategy Implementation in a Service Industry: A Study of Electricity Distribution Companies in the Sultanate of Oman. International Journal of Business and Social Science, 5, 169-183. http://ijbssnet.com/journals/Vol_5_No_9_1_August_2014/15.pdf

[20] Abok, A.M. (2013) Factors Affecting Effective Implementation of Strategic Plans in Non-Governmental Organizations in Kenya. Ph.D. Thesis, Jomo Kenyatta University of Agriculture and Technology, Kenya.

[21] Hailey, J. and James, R. (2004) "Trees Die from the Top": International Perspectives on NGO Leadership Development, Voluntas: International Journal of Voluntary and Nonprofit Organizations, 15, 343-353. https://doi.org/10.1007/s11266-004-1236-8

[22] Schwenger, D., Straub, T. and Borzillo, S. (2014) Non-Governmental Organizations: Strategic Management for a Competitive World. Journal of Business Strategy, 35, 11-19. https://doi.org/10.1108/JBS-11-2013-0105

[23] Janicijevic, N. (2013) The Mutual Impact of Organizational Culture and Structure. Economic Annals, 58, 35-60. https://doi.org/10.2298/EKA1398035J

[24] Rutherford, K.R. (2000) Internet Activism: NGOs and the Mine Ban Treaty. International Journal on Grey Literature, 1, 99-106 https://doi.org/10.1108/14666180010345528

[25] TREC (2011) Training Resource for the Environment Community Organizational Effectiveness Assessment Report.

[26] Mahmood, K., Hameed, A. and Haider, S.J. (2005) Library Fundraising in Pakistan. Library Management, 26, 429-438. https://doi.org/10.1108/01435120510631729

[27] AFP (2016) Association of Fundraising Professionals Fundraising Effectiveness Project 2016. http://afpfep.org/reports

[28] Munin, N. (2013) NGOs, Multinational Enterprises and Gender Equality in Labor 
Markets: A Political Economy of Conflicting Interests. Journal of Multidisciplinary Research, 5, 5-26.

https://www.questia.com/library/journal/1P3-3092421131/ngos-multinational-enter prises-and-gender-equality

[29] Schneider, S.K. and George, W.M. (2010) Servant Leadership versus Transformational Leadership in Voluntary Service Organizations. Leadership \& Organization Development Journal, 32, 60-77.

[30] Phillips, R. (2015) How “Empowerment” May Miss Its Mark: Gender Equality Policies and How They Are Understood in Women's NGOs. Voluntas: International Journal of Voluntary and Nonprofit Organizations, 26, 1122-1142. https://doi.org/10.1007/s11266-015-9586-y

[31] Richard, J.P., Devinney T.M., Yip, G.S. and Johnson, G. (2009) Measuring Organizational Performance: Towards Methodological Best Practice. Journal of Management, 35, 718-804.

[32] Markiewicz, P. (2011) Change Management in the Strategy Implementation Process. Intellectual Economics, 5, 257-267.

https://www3.mruni.eu/ojs/intellectual-economics/article/view/818

[33] Pearce, J. and Robinson, R. (2013) Strategic Management: Strategy Formulation Implementation and Control. 13th Edition, McGraw-Hill/Irwin, New York.

[34] Pesic, M.A. (2007) Six Sigma Philosophy and Resource-Based Theory of Competitiveness: An Integrative Approach. Economics and Organization, 4, 199-208. http://facta.junis.ni.ac.rs/eao/eao200702/eao200702-12.pdf

[35] Johnson, G., Scholes, K. and Whittington, R. (2008) Exploring Corporate Strategy. 8th Edition, Prentice Hall, Harlow, England.

[36] Ombaka, B., Machuki, V.N. and Mahasi, J. (2015) Organizational Resources, External Environment, Innovation and Firm Performance: A Critical Review of Literature. DBA Africa Management Review, 5, 60-74.

[37] Kariuki, J. and Kilika, J.M. (2016) Organization Capability, Innovation and Competitive Advantage: An Integrative Theoretical Framework Review of Literature. The International Journal of Business and Management, 5, 42-51. http://www.theijbm.com/wp-content/uploads/2017/02/5.-BM1702-008.pdf

[38] Martin, K.D., Cullen, J.B., Johnson, J.L. and Parboteeah, K.P. (2007) Deciding to Bribe: A Cross-Level Analysis of Firm and Home Country Influences on Bribery Activity. Academy of Management Journal, 50, 1401-1422. https://doi.org/10.5465/amj.2007.28179462

[39] Jang, S.H. (2013) The Offensive Framework of Resource Based View (RBV): Inhibiting Others from Pursuing Their Own Values. Journal of Management and Strategy, 4, 62-69. http://www.sciedu.ca/journal/index.php/jms/article/download/2431/1345

[40] Tarafdar, M. and Gordon, S.R. (2007) Understanding the Influence of Information Systems Competencies on Process Innovation: A Resource-Based View. The Journal of Strategic Information Systems, 16, 353-392. https://doi.org/10.1016/j.jsis.2007.09.001

[41] Herstatt, C. and Kalogerakis, K. (2005) How to Use Analogies for Breakthrough Innovations. International Journal of Innovation and Technology Management, 2, 331-347. https://doi.org/10.1142/S0219877005000538

[42] Waelde, C. (2001) The Quest for Access in the Digital Era: Copyright and the Internet. Journal of Information Law and Technology, 6, No. 1. http://www2.warwick.ac.uk/fac/soc/law/elj/jilt/2001_1/waelde/ 
[43] Bromiley, P. and Papenhausen, C. (2003) Assumptions of Rationality and Equilibrium in Strategy Research: The Limits of Traditional Economic Analysis. Strategic Organization, 1, 413-437. https://doi.org/10.1177/14761270030014003

[44] Leiblein, M.J. (2003) The Choice of Organizational Governance Form and Performance: Predictions from Transaction Cost, Resource-Based, and Real Options Theories. Journal of Management, 29, 937-961. https://doi.org/10.1016/S0149-2063(03)00085-0

[45] Kraaijenbrink, J., Spender, J.C. and Groen, A. (2009) The Resource-Based View: A Review and Assessment of Its Critiques.

[46] Amagoh, F. (2008) Perspectives on Organizational Change: Systems and Complexity Theories. The Innovation Journal: The Public Sector Innovation Journal, 13, 1-14.

[47] Onday, O. (2016) The Relationship between Concepts of Rational, Natural and Open Systems: Managing Organizations Today. International Journal of Management Sciences and Business Research, 5, 40-48.

[48] Kebaya, E., Okibo, W.B. and Nyangau, A. (2015) Effects of Cultural Change on Strategic Planning in the Banking Sector: A Case of Commercial Banks in Kisii Central Business District, Kenya. The International Journal of Business and Management, 3, 74-85.

[49] Itkin, H. and Nagy, M. (2014) Theoretical and Practical Use of Metaphors in Organizational Development and Beyond. Pannon Management Review, 3, 37-72. http://pmr.uni-pannon.hu/articles/3_4_itkin_nagy.pdf

[50] Beeson, I. and Davis, C. (2000) Emergence and Accomplishment in Organizational Change. Journal of Organizational Change Management, 13, 178-189. https://doi.org/10.1108/09534810010321508

[51] Hannagan, T. and Bennett, R. (2008) Management: Concepts and Practices. 3rd Edition, Financial Times: Prentice Hall, Pearson, New York.

[52] Brenes, E.R., Mena, M. and Molina, G.E. (2008) Key Success Factors for Strategy Implementation in Latin America. Journal of Business Research, 61, 590-598. https://doi.org/10.1016/j.jbusres.2007.06.033

[53] Lagerspetz, M., Rikmann, E. and Ruutsoo, R. (2002) The Structure and Resources of NGOs in Estonia. Voluntas. International Journal of Voluntary and Nonprofit Organizations, 13, 73-87. https://doi.org/10.1023/A:1014710229970

[54] Ciucescu, N. (2012) A Study on Financial Resources of NGOs, Studies and Scientific Researches. Economics Edition, 16/17, 113-119.

[55] Baur, D. and Schmitz, H.P (2012) Corporations and NGOs: When Accountability Leads to Co-Optation. Journal of Business Ethics, 106, 9-21. https://doi.org/10.1007/s10551-011-1057-9

[56] Ismail, A.I., Rose, R.C., Uli, J. and Abdulla, H. (2012) The Relationship Between Organizational Resources, Capabilities, Systems and Competitive Advantage. Asian Academy of Management Journal, 17, 151-173.

http://web.usm.my/aamj/17.1.2012/aamj_17.1.8.pdf

[57] Parthasarathy, V. (2013) Social Marketing Strategies of Successful NGOs: A Strategic Perspective with Reference to Selected NGOs in the States of Karnataka and Tamil Nadu. DHARANA-Bhavan's International Journal of Business, 7, 28-62.

[58] Ndegwah, D.M. (2014) Factors Affecting the Implementation of Strategic Plans in Public Secondary Schools in Nyeri County, Kenya. International Review of Management and Business Research, 3, 993-1002. 
http://www.irmbrjournal.com/papers/1402555804.pdf

[59] Muthoni, W.M. and Kavale, S. (2015) Factors Influencing Strategy Implementation of Water Supply Firms in Kenya: Case Study of Mombasa Water Supply and Sanitation Limited. International Journal of Sciences: Basic and Applied Research (IJSBAR), 22, 191-211.

[60] Abok, A., Waititu, A., Ogutu, M. and Ragui, M. (2013) A Resource-Dependency Perspective on the Implementation of Strategic Plans in Non-Governmental Organizations in Kenya. Prime Journal of Social Science, 2, 296-302. 